\title{
N-butyl-2-cyanoacrylate plug on fundal varix: persistence 3 years after sclerosis
}

\author{
A. Sáenz de Miera Rodríguez, R. Baltar Arias ${ }^{1}$, S. Vázquez Rodríguez ${ }^{1}$, W. Díaz Saa ${ }^{1}$, J. L. Ulla Rocha ${ }^{1}$, \\ J. Vázquez-Sanluis ${ }^{1}$ and E. Vázquez Astray ${ }^{1}$
}

Services of Oncology and ${ }^{1}$ Digestive Diseases. Complexo Hospitalario de Pontevedra. Vigo, Pontevedra. Spain

\section{CASE REPORT}

A 52-year-old female patient with a past history of alcohol consumption (> $100 \mathrm{~g} /$ ethanol per day) was admitted in 2005 suffering from severe upper gastrointestinal bleeding with hemodynamic deterioration. After admission, she was treated with somatostatine $(6 \mathrm{mg} / 24 \mathrm{~h})$, and an urgent gastroscopy was performed. This revealed active jet bleeding from a big fundal varix (Fig. 1). An elastic rubber band was placed that initially controlled the bleeding. However, 48 hours later, the area was checked and the varix was sclerosed (Fig. 2) with $4 \mathrm{ml}$ of N-butyl-2-cyanoacrylate (Glubran 2). The patient needed transfusion with four red-blood-cell concentrates and was transferred to the Intensive Care Unit (ICU). There was no evidence of digestive rebleeding and the patient was discharged after 14 days. Three months later, a follow-up gastroscopy was performed that showed no bleeding, but the varix was sclerosed again with $3 \mathrm{ml}$ of N-butyl-2-cyanoacrylate. Over the following years the patient refused to undergo further follow-up gastroscopies, and quit drinking alcohol.

She was admitted in July 2008 for hemorrhoidal bleeding and secondary iron deficiency anemia. At this point, the patient gave her consent to a gastroscopic examination, which showed the cyanoacrylate plug in good condition (Fig. 3) and no bleeding. A colonoscopy established that the cause of anemia was bleeding from the rectal venous plexus. During this period of time, liver function tests had improved due to alcohol withdrawal, and ultrasonophic follow-up detected no liver nodes.

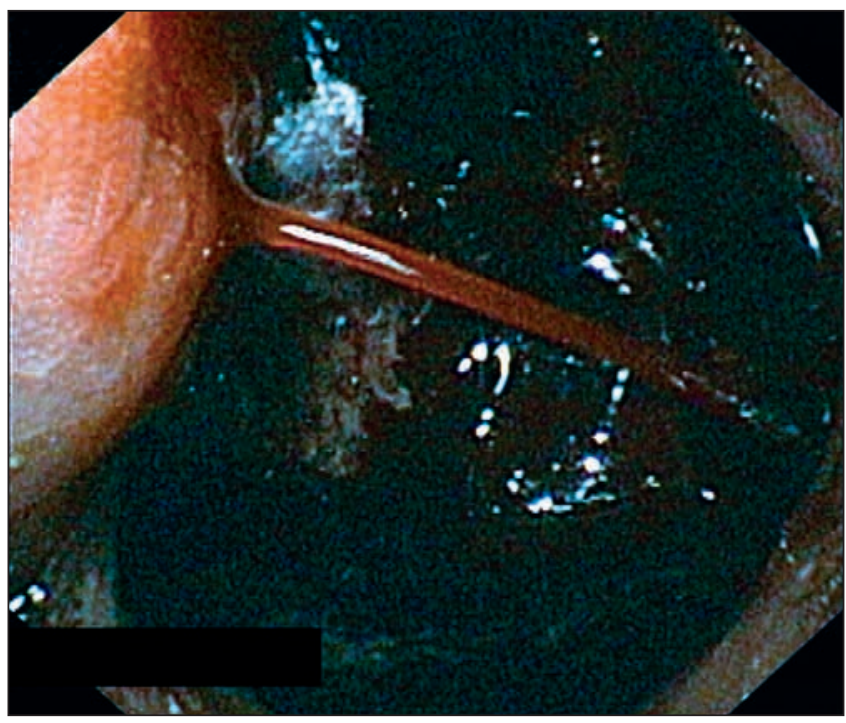

Fig. 1. Jet-bleeding fundal varix. Sangrado de variz fúndica a chorro.

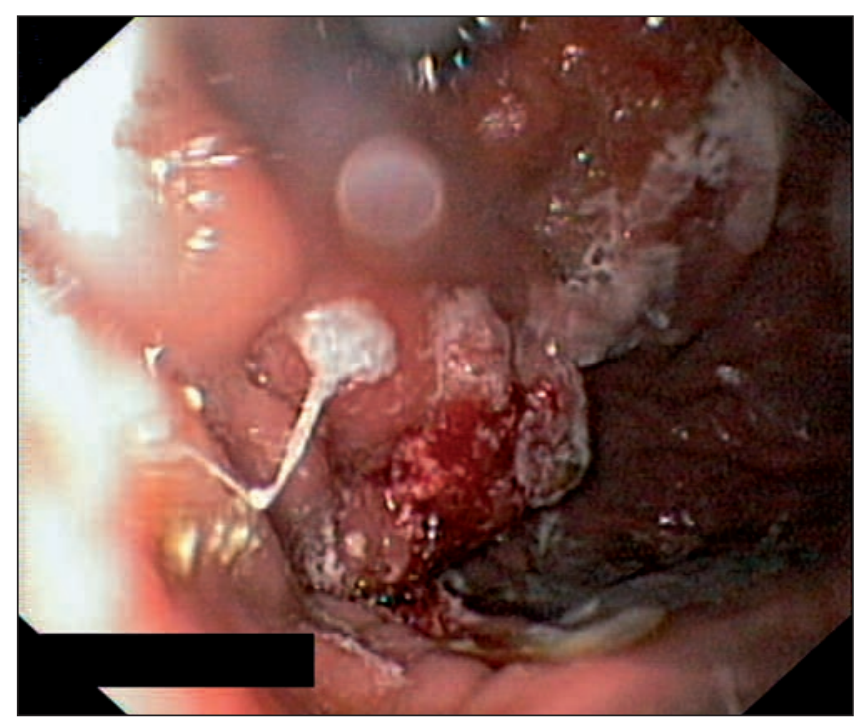

Fig. 2. Sclerotherapy using N-butyl-2-cyanoacrylate. Esclerosis con N-butil-2-cianocrilato. 


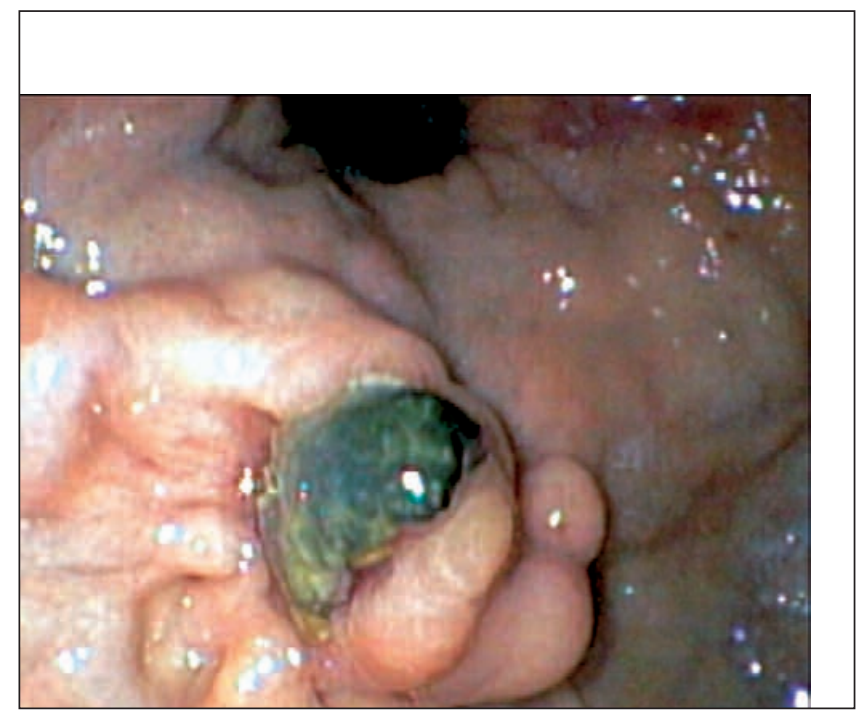

Fig. 3. Current plug over the varix with no bleeding signs. Tapón actual sobre la variz, sin datos de sangrado.

\section{DISCUSSION}

Cyanoacrylate is a sclerosing agent that is very effective for the management of bleeding gastric varices (1). It can also be used in combination with other methods, including elastic band ligation (2), to achieve low bleeding ratios (3). The current endoscopic image shows a cyanoacrylate plug on the varix, with no bleeding relapses over this period. This was also encouraged by improved liver function due to alcohol use discontinuation.

\section{REFERENCES}

1. Paik CN, Kim SW, Lee IS, Park JM, Cho YK, Choi MG, et al. The therapeutic effect of cyanoacrylate on gastric variceal bleeding and factors related to clinical outcome. J Clin Gastroenterol 2008; 42: 916-22.

2. Sugimoto N, Watanabe K, Watanabe K, Ogata S, Shimoda R, Sakata H, et al. Endoscopic hemostasis for bleeding gastric varices treated by combination of variceal ligation and sclerotherapy with $\mathrm{N}$-butyl-2-cyanoacrylate. J. Gastroenterol 2007; 42(7): 528-32.

3. Akahoshi T, Hashizume M, Shimabukuro R, Tanoue K, Tomikawa M, Okita $\mathrm{K}$, et al. Long term results of endoscopic hystoacryl injection sclerotherapy for gastric variceal bleeding: a 10-year experience. Surgery 2002; 131(1 Supl.): S176-81. 